\title{
1 Varieties of Post-classical and Byzantine Greek: Novel questions and approaches
}

\begin{abstract}
This chapter draws attention to the importance of studying not only linguistic variation in language, but also the patterned heterogeneity that can be related to it - in other words, linguistic varieties. Whereas the presence of varieties such as foreigner talk, female speech, colloquial language, etc. in the Classical period has received considerable attention, much less work has been done on the Post-classical and Byzantine periods, a situation which this edited volume hopes to remedy. Before outlining the contributions to the volume, we address a couple of central theoretical questions to research on linguistic varieties, such as the relationship between concepts like 'variant', 'variety' and 'variation', the modeling of varieties in terms of a 'variational space', the relationship between varieties, and the different methodologies that can be adopted to study linguistic varieties.
\end{abstract}

"The most novel and difficult contribution of sociolinguistic description must be to identify the rules, patterns, purposes, and consequences of language use, and to account for their interrelations." (Hymes 1974: 75)

\section{Introduction}

For a long time, linguistic variation was conceived of as a problem, rather than a topic worthy of scholarly attention. Under the impulse of William Labov and others, however, scholars came to recognize the central importance of heterogeneity in language, which in turn led to the establishment of sociolinguistics as a discipline. Scholars working within this discipline have investigated the correlation between linguistic variants and contextual variables such as age, gender, social class, social distance, etc. Of course, in actual language use, variants (and to some extent, variables) do not occur in an isolated fashion; rather, there is patterned heterogeneity. In this spirit, scholars have turned their attention to the description of linguistic varieties or "lects", such as chronolects, dialects, idiolects, ethnolects, genderlects, regiolects, sociolects, technolects, etc. in a great number of languages. ${ }^{1}$

1 For good introductions to linguistic varieties see Kiesling (2011), Sinner (2013); for an encyclopedic overview see Ammon et al. (2004-2006). 
The main aim of this volume is to explore varieties of Post-classical and Byzantine Greek. When it comes to Classical Greek, varieties have received quite some attention: scholars have discussed varieties such as scientific and medical language, female speech, foreigner talk, religious language, colloquial language, profane and obscene language, etc. ${ }^{2}$ Studies have also been written on individual authors and linguistic features, such as Thesleff (1967) on registers in Plato, Trenkner (1960) on paratactic structuring, and Dickey (1996) on forms of address. In comparison with Classical Greek, relatively little research has been done on Post-classical and Byzantine Greek, with the exception of Biblical Greek. ${ }^{3}$ This is rather remarkable, since, as one of us has written in the past, "the situational characteristics of our Post-classical textual witnesses diverge to a much greater extent than what is the case for Classical Greek, making Post-classical Greek more suitable for diachronic (register-based) research" (Bentein 2013: 35).

In recent years, a number of edited volumes have appeared, which have started to rectify this situation: these include Evans and Obbink's (2010) The language of the papyri, Leiwo et al.'s (2012) Variation and change in Greek and Latin, Hinterberger's (2014) The language of Byzantine learned literature, and our own Variation and change in Ancient Greek tense, aspect and modality (Bentein, Janse \& Soltic 2017). The present book is intended to complement these volumes, which mostly deal with linguistic features, rather than patterns of linguistic features, that is, linguistic varieties. In addition to the discussion of specific varieties, this book explores a number of key research questions:

- Which linguistic models can be used for the description and analysis of varieties?

- What is the relationship between different dimensions of variation, for example between the diachronic and the diastratic dimension?

- What role do idiolects play for the description of language variation?

- To what extent do non-congruent features (i.e. features belonging to different, or even opposed varieties) occur in texts?

- What is the relevance of and relationship between documentary and literary texts as sources of variation?

- At which linguistic levels (phonological, morphological, syntactic, lexical) can varieties be described?

2 See, e.g., Bain (1984), Lopez Eire (1996), van der Eijck (1997), Willi (2003), Fögen (2009), Schironi (2010), Janse (2014) and corresponding entries in EAGLL; for general overviews see Clackson (2015), Janse (2020).

3 On the Greek of the New Testament see e.g. Janse (2007). On the Greek of the Fathers, see e.g. Bentein (2015). 


\section{Theoretical background}

Space does not permit us to fully discuss the broad topic of linguistic variation, more specifically linguistic varieties, but we do want to briefly outline some of the key issues which are immediately relevant to the contributions to this volume, and which will remain essential for future students of linguistic varieties. In what follows, we address the following four questions: (i) how do the notions of (linguistic) "variant”, "variety” and "variation" relate to each other?, (ii) can the notion of variety be theorized in a more precise way?, (iii) how do varieties relate to each other?, and (iv) what methodology should one adopt when studying linguistic varieties?

\subsection{Variant, variety, variation}

Our first point concerns the key notions (linguistic) "variant", "variety" and "variation". As scholars have argued, both variants and varieties are indicative of linguistic variation, that is, "differences in linguistic form without (apparent) changes in meaning” (Walker 2010: 16). As Hudson's (1996: 22) definition of linguistic variety indicates, however, variety forms a more global category, which generalizes over individual speakers and individual linguistic items: "we may define a variety of language as a set of linguistic items with similar social distribution" (Hudson 1996: 22). Well-known in this regard is Halliday's (1978) distinction between two major types of varieties, that is, varieties according to user ("dialects") and varieties according to use ("registers").

Many questions surround the two key notions of linguistic variety and linguistic variation: for example, scholars have discussed whether there are sufficient criteria to be able to speak about a variety, and how to draw boundaries between varieties, questions well known from dialectology. The distinction between dialects and registers, too, does not seem absolute: several scholars have proposed to recognize "social dialects". These and other difficulties have led Hudson (1996: 68) to even completely deny the validity of the notion "variety": "we have come to essentially negative conclusions about varieties. . . We have suggested that the only way to solve these problems is to avoid the notion 'variety' altogether as an analytical or theoretical concept." Hudson (1996: 48-49) opposes an "item-based" approach (focusing on linguistic variants) to a "variety-based approach" (focusing on linguistic varieties), heavily favoring the 
first type of approach. ${ }^{4}$ Evidently, we do not support Hudson's (1996) proposal to completely abandon varieties, and to focus on an item-based approach.

Linguistic variants are not without difficulty either: for example, sociolinguistic studies typically posit as a working principle the semantic equivalency of the variants that together make up a variable, but scholars have questioned the existence/possibility of complete semantic equivalency. ${ }^{5}$ We feel it is important to be aware of these and other theoretical difficulties, and to combine both types of approaches as much as possible.

\subsection{Variational space}

The second issue which we want to address here is how we can theorize varieties and the situational dimensions that go behind them in a more precise way. A useful starting point in this regard is the German notion of Variationsraum or "variational space". Klein provides the following definition: ${ }^{6}$ "Diese Dimensionen [der Variation] können sehr unterschiedlicher Art sein; sie bilden insgesamt so etwas wie einen Raum, in dem sich die sprachliche Variation bewegt; diesen Raum bezeichne ich als Varietätenraum” (1976: 29) .

Sociolinguistic research has attempted to define language's variational space more precisely: since the 1960s, various proposals have been made by scholars such as Coseriu (1969), Halliday (1978), Dittmar (1997) and Berruto (2004). According to the model first introduced by Coseriu (1969), four general dimensions can be distinguished: (a) the "diachronic" dimension (variation in time), (b) the "diatopic" dimension (variation in space), ${ }^{7}$ (c) the "diastratic" dimension (variation according to the speaker's social status), and (d) the "diaphasic" dimension (variation in communicative settings). ${ }^{8}$ If and how these general dimensions can be further

4 So e.g. Hudson (1996: 49): “the notion 'linguistic variety' is an optional extra, available when needed to capture generalisations that apply to very large collections of linguistic items, but by no means the only mechanism, or even the most important mechanism, for linking linguistic items to their social context".

5 Lavandera (1978: 181), for example, has proposed to relax the condition that the referential meaning of all variants must be identical, and has suggested to replace it with a condition of "functional comparability".

6 See more recently Lange, Weber \& Wolf (2012: 1) "a variational space depicts the sum total of all varieties of a single language."

7 This is probably the best studied dimension; see now Auer \& Schmidt (2010).

8 Other scholars have proposed to add a "diamesic" dimension. 
subdistinguished ${ }^{9}$ is a matter of discussion, especially when it comes to the diastratic and diaphasic dimensions. Some scholars have attempted to do so by referring to the notion "lect", which stems from dialect, and offers a convenient way of describing varieties. Berruto (1987: 21), for example, specifies different types of varieties by positing them along three axes (diaphasic, diamesic, and diastratic).

Berruto's (1987) model has often been referred to in variationist studies. Whether it could be applied to Ancient Greek (Post-classical and Byzantine Greek in particular) remains to be seen. Future scholarship will need to be wary of simply applying a model developed for one language to another language. As Lüdtke and Mattheier (2005) have noted, certain variationist dimensions are more important in one language than the other:

So kann mann etwa zeigen, dass die französische Spracharchitektur wesentlich deutlicher durch die diastratische und die diaphasische Dimension geprägt ist als die deutsche, bei der (immer noch) die diatopische Dimension im Vordergund steht. Im britischen English wäre ähnlich wie im Französischen die diastratische und die diaphasische Dimension und ähnlich wie im Deutschen die diatopische Dimension zu berücksichtigen (Lüdtke \& Mattheier 2005: 34) ${ }^{10}$

Another issue that needs to be sorted out is the role of the notion "idiolect". Berruto (1987) does not take this type of lect into account, even though modern-day studies have claimed a central role for it. ${ }^{11}$ In recent years, scholars working on the language of Ancient Greek documentary sources, too, have come to stress its central importance. ${ }^{12}$

\subsection{Varieties and variants: Interrelationships}

Our next point concerns the relationship between linguistic varieties, and the social dimensions that go behind them. Coseriu (1980), among others, confronted

9 Cf. Berruto (2004: 193): "weiter gibt es diesen Dimensionen untergeordnete, spezifischere Faktoren, die für detailliertere Klassifikationen zu berücksichtigen sind." ["Furthermore, there are subordinate, more specific factors to these dimensions that must be considered for more detailed classifications."]

10 "So, for example, one can show that the linguistic architecture of French is much more clearly characterized by the diastratic and the diaphasic dimensions than that of German, where the diatopic dimension is (still) in the foreground. In British English, one would have to take into account the diastratic and the diaphasic dimension, similar to French, and the diatopic dimension, similar to German."

11 Cf. Oksaar (2000).

12 See e.g. Evans (2015), Nachtergaele (2015), Leiwo (2017). 
this problem by arguing for a hierarchical relationship between three types of varieties, which he calls Dialekt (a "syntopic" unit), Sprachniveau (a "synstratic" unit [also called "sociolect"]) and Sprachstil (a "synphasic" unit [also called "register"]). Berruto (1993: 11) subsequently elaborated Coseriu's model, by arguing that diatopic varieties can also serve as diastratic varieties, diastratic varieties as diaphasic varieties, and diaphasic as diamesic varieties, but not the other way around (cf. Sinner 2013: 73).

As one can see, Coseriu's (1980) and Berruto's (1993) treatments do not take into account the diachronic dimension, which is not uncommon, as noted by Sinner (2013: 231):

Die diachrone Perspektive wurde in vielen varietätenlinguistischen Arbeiten und Darstellungen von Varietätengefügen lange Zeit nur am Rande erwähnt. Manchmal wird dies damit begründet, dass die historische Perspektive ein zu umfangreiches oder ein zu komplexes Thema darstelle, manchmal wird deutlich gemacht, dass der Grund darin liegt, dass die diachrone Perspektive mit den anderen Varietätendimensionen nicht vergleichbar sei, weil es nicht um Varietäten, sondern ihren Wandel gehe. ${ }^{13}$

Clearly, future studies need to better integrate diachronic change in their modelling of varieties. Nabrings (1981: 38) has suggested that this can be thought of in terms of the succession of "zeitlich aufeinanderfolgende 'homogene' sprachliche Systeme", ${ }^{14}$ but whether the distinction between diachronic layers is so simple is questionable. ${ }^{15}$

Next to the interrelationship of varieties, one can also inquire about the interrelationship between the linguistic features that characterize varieties: at which levels can these features be found, and to what extent do they co-occur? Is it true that the morpho-syntactic dimension is the least characterizing for linguistic varieties, as scholars have claimed? ${ }^{16}$ Do we posit "co-textual congruence" as a prerequisite, or can we also allow for "non- or fractional congruence"? ${ }^{17}$ James (2014: 14) has noted that non-congruence is often the case between the orthographic/phonological and syntactic level, but perhaps similar observations can be made inside one and the same level, as suggested by Halla-aho (2010: 172): “even within one

13 "The diachronic perspective has long been mentioned only marginally in many variationist-linguistic works and representations of varieties. On some occasions this is justified by the fact that the historical perspective is too extensive or too complex a topic, whereas on others it is made clear that the reason is that the diachronic perspective is not comparable with the other variational dimensions, because it is not about varieties, but about their change."

14 "Chronologically successive 'homogeneous' linguistic systems."

15 Cf. Sinner (2013: 232).

16 Cf. Hudson (1996: 43-45), Berruto (2004: 193), Bentein (this volume).

17 Cf. Agha (2007). 
level, e.g. syntactic, it may be possible to identify different registers occurring next to each other, for example typical letter phrases and colloquial syntax". How problematic this is for the study of varieties remains to be studied.

\subsection{Methodology}

To conclude this discussion, we briefly want to go into methodology. Two main approaches are typically distinguished, referred to as "quantitative" vs. "qualitative". Whereas William Labov is generally acknowledged to be the main proponent of the quantitative approach, known as "variationist sociolinguistics", ${ }^{18}$ John Gumperz has formed the leading figure of the qualitative approach, known as "interactional sociolinguistics". ${ }^{19}$ When it comes to Ancient Greek, some attempts have been made for a quantitative approach to the study of variation and varieties, but by and large scholars tend to adopt an interpretative, qualitative approach, among others because creating statistics is a hugely time-consuming task, and it is not always clear what it contributes.

Horrocks (2007: 630-631), for example, has proposed a classification of writing styles in Post-classical Greek, distinguishing between three major styles, called "basic/non-literary"20, "official and scientific/technical"21, and "literary"22. We both find this an original and impressive proposal, but we can't help wondering what the classification would look like if we let the data speak for themselves, that is, when we ask the computer to analyze which features most often accompany each other. This is the approach propagated by Biber (1994), which has had very few followers in Greek linguistics so far.

Another methodological point that is worth considering is which sources to use for our investigations, and how to approach them. Ancient Greek is a corpus language, so out of necessity we have to work with texts. This does not mean that we do not have choices, however: older works, such as Browning's (1983) Medieval and Modern Greek, limit themselves to texts that are "spoken-like" - "authentic",

18 E.g. Labov (1994-2010).

19 E.g. Gumperz (1982).

20 Characterized, for example, by the use of $\alpha$ 'to to mark the agent in passive constructions, the use of iv $\alpha$ after verbs of commanding, the use of the genitive articular, infinitives in a final sense, etc.

21 Characterized, for example, by the frequent use of tuyxáv $\omega$ in the sense of 'to be', the use of $\varphi \eta \mu$ i with an accusative and infinitive, the use of ötı after verbs of thinking, etc.

22 Characterized, for example, by the use of the optative in subordinate clauses after pasttense main verbs, the personal passive construction, a general effort to preserve the classical future and the perfect in all their forms, etc. 
to use a term introduced by Joseph (2000) - such as documentary sources, hagiographical texts, etc. More recent works, on the other hand, such as Horrocks (2010), have argued for the importance of an inclusive approach, taking into consideration higher-register works as well. For the study of varieties, this definitely seems the best way to go.

A second, perhaps even more important methodological distinction is that between texts which report directly on the social value of linguistic features, such as stylistic manuals, scribal corrections, manuscript additions, etc., and texts which merely testify to actual language in use. Do we consider the first type of testimonies to be worthy of study? Or do we agree with modern-day observations that speakers form bad observers of social distinctions? ${ }^{23}$ Recent research has explored the value of the first type of source for both Post-classical and Byzantine Greek, ${ }^{24}$ and has come to some very interesting findings.

\section{Outline of the volume}

Linguistic varieties in Post-classical and Byzantine Greek constitute a very broad topic, which can be approached from many different angles. This is reflected by the contributions to this volume, which deal with different time periods, different dimensions and domains of variation, and use different methodologies. Broadly speaking, however, one can say that this volume consists of two main parts.

The first part of the volume (chs. 2-8) deals with linguistic varieties more narrowly speaking. Many of the contributions to this part deal with Greek in Egypt. Martti Leiwo (ch. 2) takes a broad approach, and investigates which varieties or "lects" can be distinguished. Focusing on the Roman period, Leiwo zooms in on a couple of geographical areas, in particular the Eastern desert, where the context of writing was quite different than for example in the Fayum, with a strong presence of the Roman army, the absence of scribes, and ostraca forming the standard writing material. Leiwo characterizes what he calls the "ostraca variety" as a mix of different varieties and registers, including ethnolects, idiolects, and doculects. Marja Vierros (ch. 3) specifically looks into one

23 Cf. Sinner (2013: 127-8): "es ist auch zu bedenken, dass trotz anderslautender ansichten in der sprachwissenschaft sprecher wohl i.d.r. nicht wissen, wass sie selbst - in sprachlicher hinsicht tun oder nicht tun, und normalerweise nicht einmal in der Lage sind, von ihnen selbst Gesagtes im genauen Wortlaut zu wiederholen." ["One must also consider that, despite different views in linguistics, speakers usually do not know - in linguistic terms - what they are or are not doing and are usually not even able to accurately repeat what they have said themselves."]

24 See e.g. Luiselli (2010), Cuomo (2017), Bentein (this volume). 
of the varieties mentioned by Leiwo, namely idiolect. Focusing on the archive of the Katochoi of the Sarapeion, she draws attention to several documents that are written in the own hands of the brothers Apollonius and Ptolemaeus, the archive's main figures. Vierros investigates whether it is possible to identify the idiolects of the two brothers through these autograph texts. Aikaterini Koroli (ch. 4) asks whether it is possible to speak of an "ecclesiastical" style of letter writing. She focuses on a corpus of request letters from the Late Antique period, and analyzes which strategies people use to achieve their communicative goal, that is, the satisfaction of the request. She concludes that although there are clear differences between the writers of the letters, politeness in general seems to be a priority. Victoria Fendel (ch. 5) discusses whether it is possible to identify features in the areas of verbal, nominal and discourse syntax that can be qualified as characteristic of Egyptian Greek. She argues that two of the three

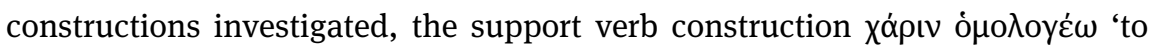
be grateful' and the predicative possessive pattern with úró 'by', can be qualified as regionalisms. Multifunctional kaí 'and', on the other hand, is better qualified as a "colloquialism”. Sofía Torallas Tovar (ch. 6) also deals with Egyptian Greek, attempting to define more accurately the Egyptian Greek lexicon. Torallas Tovar extensively discusses the sources available for such a definition, distinguishing between documentary papyri and literary sources, and outlining some of the difficulties associated with these sources. The last three contributions to the first part of the volume deal with Byzantine Greek. Geoffrey Horrocks (ch. 7), addresses the question of how Byzantine writers used "Classical” Greek. Focusing on expressions of futurity and modality, Horrocks argues that these writers were subject to interference from their natural speech, especially in more abstract areas of grammar such as syntax and semantics. He concludes that high-register Byzantine Greek should be considered a variety of its own, rather than an exact copy of Classical Greek. Martin Hinterberger (ch. 8) also explores the question of highregister classicizing Greek, but from a different angle. He juxtaposes Nicetas Choniates' (XIII CE) History, which was written in high-register classicizing prose, with its metaphrasis, which is composed in a much simpler variety of Greek, sometimes called "Byzantine written koiné”. Hinterberger explores the differences between these two texts at different linguistic levels, but also notes that there are shared linguistic characteristics, which leads him to question how these varieties can be accurately defined and distinguished. Mark Janse (ch. 9) analyzes the linguistic differences of two variants of a traditional medieval song from Cappadocia as evidence for diachronic variation in Medieval and Cappadocian Greek. He shows how the largely formulaic language of such traditional songs allows for the retention of archaisms as well as the insertion of innovative forms. Apart from loanwords and grammatical patterns borrowed 
from Turkish, the so-called 'Byzantine residue' of Cappadocian offers a unique and hitherto unexplored glimpse of language variation in Medieval Greek.

The second part of the volume (chs. 10-16) addresses the linguistic features that are indicative of varieties of Post-classical and Byzantine Greek, taking into consideration different linguistic levels. Carla Bruno (ch. 10) discusses tense variation in a small corpus of Ptolemaic private papyri, focusing on the use of the present, aorist and perfect indicative, framing her observations in the concept of the "epistolary dialogue" and noting that the deictic center of the statement cannot only be anchored to the time of writing (the addressor's perspective) but also to the time of reading (the addressee's perspective). Jerneja Kavčič (ch. 11) also goes into tense usage, but in a different context: she studies expressions of anteriority and posteriority in infinitive clauses, and analyzes to what extent official papyrus texts reflect the "Attic" norm (that is, Classical Greek). Whereas the frequent use of the perfect infinitive in official papyrus texts cannot be called an influence of Classical Greek, that of the future infinitive may be. Joanne Vera Stolk (ch. 12) concentrates on orthographic variation in documentary sources, which she tries to relate to the register of the text. After proposing a general classification of the different types of documentary sources, she shows that there seem to be convincing correlations between orthography and social context. She argues, however, that there may also be conflicts between orthography and social context, for which the Sitz im Leben of the document needs to be taken into account. Emilio Crespo (ch. 13) also studies orthographic variation, but on a much smaller scale, focusing on a single archive, that of the tax collector Nemesion. Crespo poses the question whether the orthographic variation in this archive is best interpreted in terms of idiolect, register, dialect, or sociolect. He argues that we are most likely dealing with a sociolect of Koinè Greek which is characterized by a pronunciation with interference from Coptic. Julie Boeten (ch. 14) discusses metrical variation in a hitherto completely ignored corpus

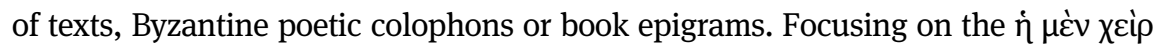
$\dot{\eta}$ ypó $\psi \alpha \sigma \alpha$ colophon, she argues that metrical variants do not simply represent mistakes by the scribe. Referring to the notion of "information unit", she suggests that the stringing together of units was, perhaps, deemed more important than the resulting number of syllables. Staffan Wahlgren (ch. 15) takes into account different types of syntactic variation, concerning verb forms, subordination, particles and case syntax. Focusing on the oeuvre of Symeon the Logothete (X CE), Wahlgren analyzes and compares the use of these different linguistic features in descriptive, narrative and argumentative sections. In the final chapter to this volume, Klaas Bentein (ch. 16) also takes a broad approach, by investigating whether variation at the syntactic level should be considered distinct from variation at other linguistic levels. For this purpose, he compares different types of sources 
from different time periods, proposing a distinction between "user-centered sources" and "observer-centered sources".

\section{References}

Agha, A. 2007. Language and social relations: Structure, use and social significance. Cambridge: Cambridge University Press.

Ammon, Ulrich, Norbert Dittmar, Klaus J. Mattheier \& Peter Trudgill (eds.). 2004-2006. Sociolinguistics: An international handbook of the science of language and society, $2^{\text {nd }}$ ed. Berlin: de Gruyter.

Auer, Peter \& Jürgen Erich Schmidt (eds.). 2010. Language and space: An international handbook of linguistic variation. Vol. 1. Theories and methods. Berlin: de Gruyter Mouton.

Bain, David. 1984. Female speech in Menander. Antichthon 18. 24-42.

Bentein, Klaas. 2013. Register and the diachrony of Post-classical and Early Byzantine Greek. Revue Belge de Philologie et d'Histoire 91. 5-44.

Bentein, Klaas. 2015. The Greek of the Fathers. In Ken Perry (ed.), The Wiley-Blackwell companion to Patristics, 456-470. Oxford: Wiley-Blackwell.

Bentein, Klaas, Mark Janse \& Jorie Soltic (eds.). 2017. Variation and change in Ancient Greek tense, aspect and modality. Leiden: Brill.

Berruto, Gaetano. 1987. Sociolinguistica dell'italiano contemporaneo. Roma: Carocci.

Berruto, Gaetano. 1993. Varietà diamesiche, diastratiche, diafasiche. In Antonio A. Sobrero (ed.), Introduzione all'italiano contemporaneo, 37-92. Bari: Laterza.

Berruto, G. 2004. Sprachvarietät - Sprache (Gesamtsprache, historische Sprache). In Ulrich Ammon, Norbert Dittmar, Klaus J. Mattheier \& Peter Trudgill (eds.), Sociolinguistics: An international handbook of the science of language and society, $2^{\text {nd }}$ ed. (2004-2006), vol. 1, 188-195. Berlin: de Gruyter.

Biber, Douglas. 1994. An analytical framework for register studies. In Douglas Biber \& Edward Finegan (eds.), Sociolinguistic perspectives on register, 31-56. Oxford: Oxford University Press.

Browning, Robert. 1983. Medieval and Modern Greek, $2^{\text {nd }}$ ed. Cambridge: Cambridge University Press.

Clackson, James. 2015. Language and society in the Greek and Roman worlds. Cambridge: Cambridge University Press.

Coseriu, Eugenio. 1969. Einführung in die strukturelle Linguistik. Tübingen: Narr.

Coseriu, Eugenio. 1980. 'Historische Sprache' und 'Dialekt'. In Joachim Göschel, Pavle Ivic \& Kurt Kehr (eds.), Dialekt und Dialektologie: Ergebnisse des Internationalen Symposions 'Zur Theorie des Dialekts', Marburg/Lahn, 5-10 September 1977, 106-122. Wiesbaden: Steiner.

Cuomo, Andrea Massimo. 2017. Medieval textbooks as a major source for historical sociolinguistic studies of (high register) Medieval Greek. Open Linguistics 3. 442-455.

Dickey, Eleanor. 1996. Greek forms of address: From Herodotus to Lucian. Oxford: Oxford University Press.

Dittmar, Norbert. 1997. Grundlagen der Soziolinguistik. Tübingen: Narr. 
Eijk, Philip J. van der. 1997. Towards a rhetoric of ancient scientific discourse. In Egbert J. Bakker (ed.), Grammar as interpretation: Greek literature in its linguistic contexts, 77-129. Leiden: Brill.

Evans, Trevor V. \& Dirk D. Obbink (eds.). 2010. The language of the papyri. Oxford: Oxford University Press.

Evans, Trevor V. 2015. Idiolect and aspectual choice in Ancient Greek: Evidence from the Zenon Archive and the Greek Pentateuch. In James K. Aitken \& Trevor V. Evans (eds.), Biblical Greek in context: essays in honour of John A. L. Lee, 59-90. Leuven: Peeters.

Fögen, Torsten. 2010. Female speech. In Egbert J. Bakker (ed.), A companion to the Ancient Greek language, 311-326. Malden: Wiley-Blackwell.

Gumperz, John J. 1982. Discourse strategies. Cambridge: Cambridge University Press.

Halla-aho, Hilla. 2010. Linguistic varieties and language level in Latin non-literary letters. In Trevor V. Evans \& Dirk D. Obbink (eds.), The language of the papyri, 171-183. Oxford: Oxford University Press.

Halliday, M.A.K. 1978. Language as social semiotic: The social interpretation of language and meaning. London: Arnold.

Hinterberger, Martin (ed.). 2014. The language of Byzantine learned literature. Turnhout: Brepols.

Horrocks, Geoffrey C. 2007. Syntax: from Classical Greek to the Koine. In A.-F. Christidis (ed.), A history of Ancient Greek: From the beginnings to Late Antiquity, 618-631. Cambridge: Cambridge University Press.

Horrocks, Geoffrey C. 2010. Greek: A history of the language and its speakers, $2^{\text {nd }}$ ed. Malden: Wiley-Blackwell.

Hudson, Richard A. 1996. Sociolinguistics, $2^{\text {nd }}$ ed. Cambridge: Cambridge University Press. Hymes, Dell H. 1974. Foundations in sociolinguistics: An ethnographic approach. Philadelphia: University of Pennsylvania Press.

James, Patrick. 2014. Papyri, language of. EAGLL [online edition].

Janse, Mark. 2007. The Greek of the New Testament. In A.-F. Christidis (ed.), A history of Ancient Greek: From the beginnings to Late Antiquity, 646-653. Cambridge: Cambridge University Press.

Janse, Mark. 2014. Aischrology. EAGLL [online edition].

Janse, Mark. 2020. The sociolinguistic study of Ancient Greek and Latin. Arctos 54, in press. Joseph, Brian D. 2000. Textual authenticity: Evidence from Medieval Greek. In Susan

C. Herring, Pieter van Reenen \& Lene Schøsler (eds.), Textual parameters in older languages, 309-29. Amsterdam: Benjamins.

Kiesling, Scott F. 2011. Linguistic variation and change. Edingburgh: Edinburgh University Press.

Klein, Wolfgang. 1976. Sprachliche Variation. Studium Linguistik 1. 29-46.

Labov, William. 1994-2010. Principles of linguistic change. Vol. 1-3. Malden: Blackwell.

Lange, Claudia, Beatrix Weber \& Göran Wolf. 2012. Introduction. In Claudia Lange, Beatrix

Weber \& Göran Wolf (eds.), Communicative spaces: Variation, contact, and change:

Papers in honour of Ursula Schaefer, 1-6. Frankfurt am Main: Lang.

Lavandera, Beatriz. 1978. Where does the sociolinguistic variable stop? Language in Society 7. 171-182.

Leiwo, Martti. 2017. Confusion of moods in Greek private letters of Roman Egypt. In Klaas Bentein, Mark Janse \& Jorie Soltic (eds.), Variation and change in Ancient Greek tense, aspect and modality, 242-260. Leiden: Brill. 
Leiwo, Martti, Hilla Halla-aho \& Marja Vierros (eds.). 2012. Variation and change in Greek and Latin. Helsinki: Suomen Ateenan-Instituutin säätiö.

López Eire, Antonio. 1996. La lengua coloquial de la comedia aristofánica. Murcia: Universidad de Murcia.

Lüdtke, Jens \& Klaus J. Mattheier. 2005. Variation - Varietäten - Standardsprachen. Wege für die Forschung. In Alexandra N. Lenz \& Klaus J. Mattheier (eds.), Varietäten - Theorie und Empirie, 13-38. Frankfurt am Main: Lang.

Luiselli, Raffaele. 2010. Authorial revision of linguistic style in Greek papyrus letters and petitions (AD I-IV). In Trevor V. Evans \& Dirk D. Obbink (eds.), The language of the papyri, 71-96. Oxford: Oxford University Press.

Nabrings, Kirsten. 1981. Sprachliche Varietäten. Tübingen: Narr.

Nachtergaele, Delphine. 2015. Three new letters in the Thermouthas dossier. Mnemosyne 68, 53-67.

Oksaar, Els. 2000. Idiolekt als Grundlage der variationsorientierten Linguistik.

Sociolinguistica 14, 37-42.

Schironi, Francesca. 2010. Technical languages: Science and medicine. In Egbert J. Bakker (ed.), A companion to the Ancient Greek language, 338-353. Malden: Wiley-Blackwell.

Sinner, Carsten. 2013. Varietätenlinguistik: eine Einführung. Tübingen: Narr.

Thesleff, Holger. 1967. Studies in the styles of Plato. Helsinki: Societas Philosophica Fennica. Trenkner, Sophie. 1960. Le style kaí dans le récit attique oral. Asse: van Gorcumn.

Walker, James A. 2010. Variation in linguistic systems. New York: Routledge.

Willi, Andreas. 2003. The languages of Aristophanes: Aspects of linguistic variation in Classical Attic Greek. Oxford: Oxford University Press. 
